\title{
The incidence rate of hospitalized lysosomal storage diseases in Poland in 2013-2015 based on data from the National Health Fund
}

\author{
Zapadalność szpitalna na lizosomalne choroby spichrzeniowe w Polsce w latach 2013-2015 \\ na podstawie danych Narodowego Funduszu Zdrowia
}

\author{
${ }^{1}$ Władysław Grzeszczak, 2,3 Edward Franek, ${ }^{4}$ Agnieszka Szypowska, ${ }^{5}$ Winicjusz Filipow, \\ ${ }^{6}$ Mariusz Zięba, ${ }^{6}$ Paweł Kabicz, ${ }^{6,7}$ Barbara Więckowska
}

${ }^{1}$ Chair and Department of Internal Medicine, Diabetology, and Nephrology, Silesian University of Medicine, Zabrze, Poland

${ }^{2}$ The Mossakowski Medical Research Centre, Polish Academy of Sciences, Warsaw, Poland

${ }^{3}$ Department of Internal Diseases, Endocrinology and Nephrology, Central Clinical Hospital of the Ministry of Interior Affairs and Administration, Warsaw, Poland

${ }^{4}$ Department of Paediatrics, Medical University of Warsaw, Warsaw, Poland

${ }^{5}$ Department of Research and Development and Innovative Medicine for Metabolic Diseases at the Diabetic Clinic, Nysa, Poland

${ }^{6}$ Department of Analyses and Strategy, Ministry of Health, Warsaw, Poland

${ }^{7}$ Social Insurance Department of the Warsaw School of Economics, Warsaw, Poland

\begin{abstract}
Objectives: The reported data address the incidence of lysosomal storage diseases, obtained from the public health service databases in Poland. Data are given by subtypes from the National Health Fund between 2013 and 2015.

Material and methods: Patients with lysosomal storage diseases were identified in the National Health Fund database (2013-2015). In order to ensure that the reported incidence data included only new patients. The geographic area of residence in 2013-2015 was divided into 6 parts.

Results: The incidence rate of lysosomal storage diseases in Poland is about 1.84/1 million/person/years. Other sphingolipidosis was the largest disease category, with 127 patients (incidence 1.1 patients/million habitants), follow by GM2 gangliosidosis - 29 patients (incidence 0.25 patients/million habitants). Men had a somewhat higher incidence than women (respectively IR $=2.53, \mathrm{IR}=1.84$ ). The number of deaths with lysosomal storage disease patients hospitalized between the years 2013 through 2015 is higher in young people (0-9 years old).

Conclusions: The incidence rate of lysosomal storage diseases in Poland is about 1.84 per million person-years. Other sphingolipidosis was the largest disease category, followed by GM2 gangliosidosis. The hospitalization rate of lysosomal storage diseases was higher in men. Key words:

lysosomal storage diseases, incidence rate, 2013-2015, Poland.

\section{Streszczenie}

Wstęp: Przedstawione dane dotyczące zapadalności na lizosomalne choroby spichrzeniowe pochodzą z baz danych publicznej służby zdrowia w Polsce. Dane z Narodowego Funduszu Zdrowia przedstawiono według podtypów dla okresu lat $2013-2015$.

Materiał i metody: Zidentyfikowano pacjentów z lizosomalnymi chorobami spichrzeniowymi w bazie danych Narodowego Funduszu Zdrowia (2013-2015). Aby zagwarantować, że prezentowane dane dotyczące zapadalności uwzględniają wyłącznie nowych pacjentów, geograficzny obszar zamieszkania w latach 2013-2015 podzielono na sześć części.

Wyniki: Współczynnik zapadalności na lizosomalne choroby spichrzeniowe w Polsce wynosi 1,84 na 1 milion osób rocznie. Największą kategorię chorób stanowiły inne sfingolipidozy (E75.2) - 127 pacjentów (zapadalność 1,1 pacjenta na milion mieszkańców) i gangliozydoza GM2 (E75.0) - 29 pacjentów (zapadalność 0,25 pacjenta na milion mieszkańców). Współczynnik zapadalności był nieznacznie wyższy u mężczyzn niż u kobiet (odpowiednio IR $=2,53$ i IR $=1,84$ ). Regionalne różnice w zapadalności na lizosomalne
\end{abstract}


choroby spichrzeniowe nie są istotne statystycznie. Liczba zgonów pacjentów z lizosomalnymi chorobami spichrzeniowymi hospitalizowanych w latach 2013-2015 jest wyższa u ludzi młodych (0-9 lat).

Wnioski: Współczynnik zapadalności na lizosomalne choroby spichrzeniowe w Polsce wynosi ok. 1,84 na milion osobolat. Największą kategorię chorób stanowiły odpowiednio inne sfingolipidozy i GM2 gangliozydoza. Wskaźnik hospitalizacji pacjentów z lizosomalnymi chorobami spichrzeniowymi był wyższy u mężczyzn niż u kobiet. Nie zaobserwowano statystycznie istotnych różnic między wartościami współczynnika zapadalności zarejestrowanymi w analizowanych regionach Polski.

\section{Słowa kluczowe:}

Polska, współczynnik zapadalności, Lizosomalne choroby spichrzeniowe, 2013-2015.

\section{Background}

The lysosomal storage diseases are a group of genetic disorders resulting from defective lysosomal metabolism [1]. Most Iysosomal storage diseases are characterized by a large phenotypic spectrum of unspecific disease manifestations, leading to considerable diagnostic problems. Among these disorders should be mentioned mucopolysaccharidoses, mucolipidoses, glycoprotein storage disease, and others. The enzyme deficiencies have an autosomal recessive basis, with the exception of Hunter mucopolysaccharidosis II, which is X-linked recessive, and Fabry disease, which is $X$-linked with frequent manifestations in females. The target organs are determined by the usual sites of degradation for a macromolecule. All the disorders are progressive, and many are fatal in childhood or adolescence [2]. Diagnosis of lysosomal storage diseases is difficult because there are a number of overlapping clinical features that are not specific for lysosomal storage diseases [3, 4].

There is extensive clinical, biochemical, and molecular heterogeneity within the lysosomal storage diseases. In most instances, different mutations within the structural genes for lysosomal enzymes account for varying degrees for severity from individual to individual and for the diverse combinations of visceral, skeletal, neurological, ocular, and other manifestations [5].

There are limited data on the incidence of lysosomal storage diseases, probably because of the rarity and heterogeneity of the condition [6-10]. Newborn screening pilot studies reported on average a 5-80 times higher birth prevalence than previously reported [11-14].

The reported data address the incidence of lysosomal storage diseases, obtained from the public health service databases in Poland. The data are given by subtypes from the National Health Fund from 2013 through 2015.

\section{Material and methods}

\section{Source of data}

Lysosomal storage disease patients were identified from the Polish National Health Fund database (2013-2015). In order to ensure that the reported incidence data included newly hospitalized patients, anyone previously discharged with a lysosomal storage disease diagnosis was excluded.

\section{Outcome variables}

The $10^{\text {th }}$ revision of the International Classification of Diseases (ICD-10) was used to identify all first hospital admis- sions for the outcome variables amyloidosis E75: E75.0 $\mathrm{GM}_{2}$ gangliosidosis, E75.1 other gangliosidosis, E75.2 other sphingolipidosis, E75.3 sphingolipidosis, unspecified, E75.4 neuronal ceroid lipofuscinosis, E75.5 other lipid storage disorders, and E75.6 lipid storage disorder. However, because diagnostics is time consuming, the initial discharge may be changed. Therefore, we used the discharge diagnosis of the last hospitalization. Diagnostic details are not included among the discharge data.

All individual identified entities of lysomal storage disease group belong to disorders of sphingolipid metabolism and other lipid storage disorders (ICD10: E75). However, we excluded it because of many reporting errors and trying to avoid homogeneity of the group by this one disease. In pre-analysis E75 comprises nearly $40 \%$ of all cases on the lysomal storage disease group, which disrupted the study.

\section{Individual variables}

Children, adults, males, and females were included in the study. The geographic region of residence in 2013-2015 was divided into 6 regions: Masovia and Silesia with the largest population - each of them about 5.0 million habitants), and 4 others regions (south-east, south-west, north-east, and north-west). Thus, all these regions were comparable in terms of number of habitants.

\section{Statistical analysis}

The results were calculated to provide information on the incidence rate of rare metabolic diseases in lysosomal storage diseases in Poland according to the region of residence where it occurs, age, gender, and subtypes of diagnosis. Person-years were calculated from the start of follow-up on 1 January 2013 until hospitalization for lysosomal storage diseases, death, or the closing date (31 December 2015). We used R v. 3.6.1 for the statistical analyses. Charts included in the publication were created by using the $\mathrm{R}$ data visualization library - ggplot2 version 2.1.0 and Microsoft Excel 2013.

\section{Results}

Case numbers and incidence of hospitalized lysosomal storage disease patients are shown in Table I. For the years 2013 to 2015, a total of 212 patients were identified, giving an incidence of 1.84 per million person-years. Other sphingolipidosis (E75.2) was the largest disease category with 127 patients (incidence 1.1 patients/million habitants), followed by GM2 
Table I. Numbers and incidence rate (per million person-years) for hospitalized lysosomal storage diseases patients, 2013-2015

\begin{tabular}{llllllll}
\hline Subtype (ICD-10 code) & 2013 & 2014 & 2015 & Total & $\begin{array}{l}\text { Incidence /mln } \\
\text { children-year }\end{array}$ & $\begin{array}{l}\text { Incidence/mln } \\
\text { adults-year }\end{array}$ & $\begin{array}{l}\text { Incidence/mln } \\
\text { habitants-year }\end{array}$ \\
\hline E75.0 GM² gangliosidosis & 8 & 11 & 10 & 29 & 0.43 & 0.21 & 0.25 \\
\hline E75.1 Other gangliosidosis & 7 & 2 & 2 & 11 & 0.10 & 0.10 & 0.10 \\
\hline E75.2 Other sphingolipidosis & 46 & 41 & 40 & 127 & 1.44 & 1.03 & 1.10 \\
\hline E75.3 Sphingolipidosis, unspecified & 0 & 1 & 2 & 3 & 0.00 & 0.03 & 0.03 \\
\hline E75.4 Neuronal ceroid lipofuscinosis & 3 & 6 & 5 & 14 & 0.14 & 0.12 & 0.12 \\
\hline E75.5 Other lipid storage disorders & 4 & 7 & 2 & 13 & 0.10 & 0.12 & 0.11 \\
\hline $\begin{array}{l}\text { E75.6 Lipid storage disorder, } \\
\text { unspecified }\end{array}$ & 4 & 5 & 6 & 15 & 0.05 & 0.15 & 0.13 \\
\hline All & 72 & 73 & 67 & $\mathbf{2 1 2}$ & $\mathbf{2 . 3}$ & $\mathbf{1 . 7}$ & $\mathbf{1 . 8}$ \\
\hline
\end{tabular}

Table II. Incidence rate of lysosomal storage diseases for men and women, 2013-2015

\begin{tabular}{lllllllllllll}
\hline ICD10 & Men & \multicolumn{1}{c}{ Women } & \multicolumn{7}{c}{ All } \\
\cline { 2 - 14 } & $\mathrm{N}$ & $\mathrm{IR}$ & $95 \% \mathrm{Cl}$ & & $\mathrm{N}$ & $\mathrm{IR}$ & $95 \% \mathrm{Cl}$ & $\mathrm{N}$ & $\mathrm{IR}$ & $95 \% \mathrm{Cl}$ \\
\hline E75.0 & 20 & 0.36 & 0.20 & 0.52 & 9 & 0.15 & 0.05 & 0.25 & 29 & 0.25 & 0.16 & 0.34 \\
\hline E75.1 & 5 & 0.09 & 0.01 & 0.17 & 6 & 0.10 & 0.02 & 0.18 & 11 & 0.10 & 0.04 & 0.15 \\
\hline E75.2 & 72 & 1.29 & 0.99 & 1.59 & 55 & 0.92 & 0.68 & 1.17 & 127 & 1.10 & 0.91 & 1.29 \\
\hline E75.3 & 3 & 0.05 & -0.01 & 0.11 & 10 & 0.17 & 0.06 & 0.27 & 13 & 0.11 & 0.05 & 0.17 \\
\hline E75.4 & 4 & 0.07 & 0.00 & 0.14 & 0 & 0.00 & 0.00 & 0.00 & 4 & 0.03 & 0.00 & 0.07 \\
\hline E75.5 & 4 & 0.07 & 0.00 & 0.14 & 9 & 0.15 & 0.05 & 0.25 & 13 & 0.11 & 0.05 & 0.17 \\
\hline E75.6 & 12 & 0.21 & 0.09 & 0.34 & 3 & 0.05 & -0.01 & 0.11 & 15 & 0.13 & 0.06 & 0.20 \\
\hline ALL & 120 & 2.15 & 1.76 & 2.53 & 92 & 1.54 & 1.23 & 1.86 & 212 & 1.84 & 1.59 & 2.08 \\
\hline
\end{tabular}

gangliosidosis (E75.0) with 29 patients (incidence 0.25 patients/million habitants).

Table II presents the incidence rate of lysosomal storage diseases for men and women. Overall, men had a higher incidence than women (respectively, $I R=2.53$ and $I R=1.84$ ).

The age-specific rate of hospitalization for lysosomal storage diseases is shown in Figure $1 \mathrm{~A}-\mathrm{G}^{1}$.

Regional differences in the incidence of lysosomal storage diseases are shown in Table III.

Number of deaths among patients with lysosomal storage diseases hospitalized between the years 2013 and 2015 are presented in Figure 2.

1 Data presentation on charts is based on data from 2009 to 2015 to better show the incidence rate in each age group

\section{Discussion}

The reported study provides comprehensive information on lysosomal storage diseases in the Polish population, which is approximately 38 million people, and therefore the acquired data on lysosomal storage diseases incidence are very accurate. Our research demonstrated that during the years 2013 to 2015, 212 patients with lysosomal storage diseases were hospitalized (incidence of 1.80 per million person-years).

In order to obtain reliable data in our study, we took into account the medical records of all the patients who had received services of the public healthcare system in Poland from 2013 to 2015, using National Health Found data. Data of almost all the people of Polish nationality, hospitalized in Poland, are uploaded into the National Health Found database. The National 


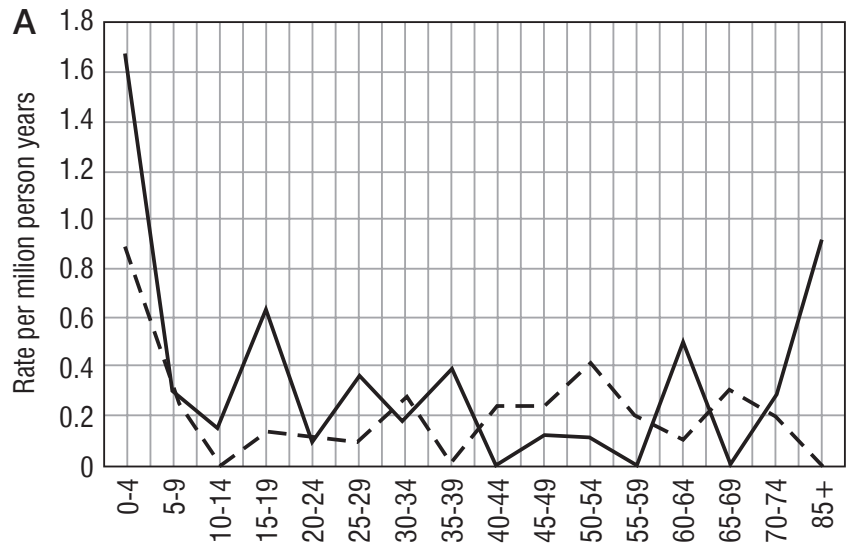

Age at diagnosis [years]

- - Women Men

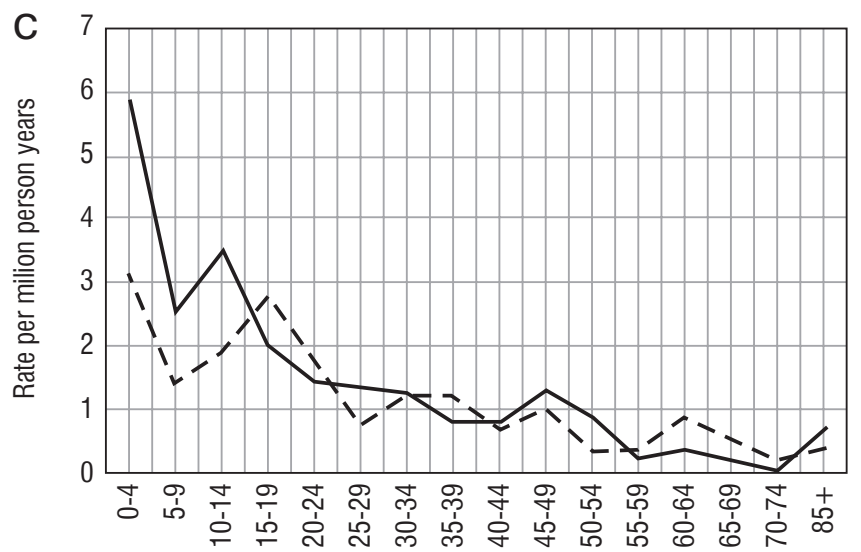

Age at diagnosis [years]

- - Women - Men

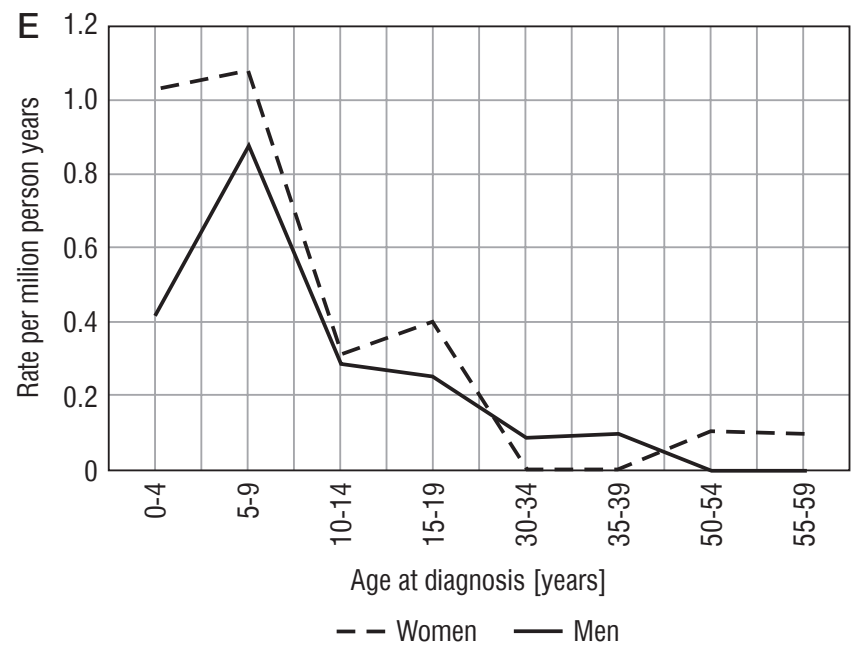

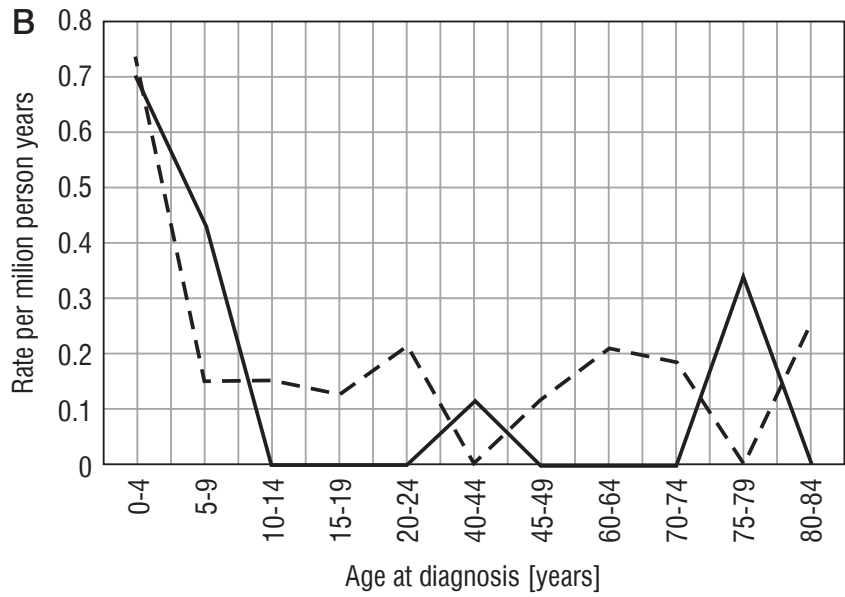

- - Women Men

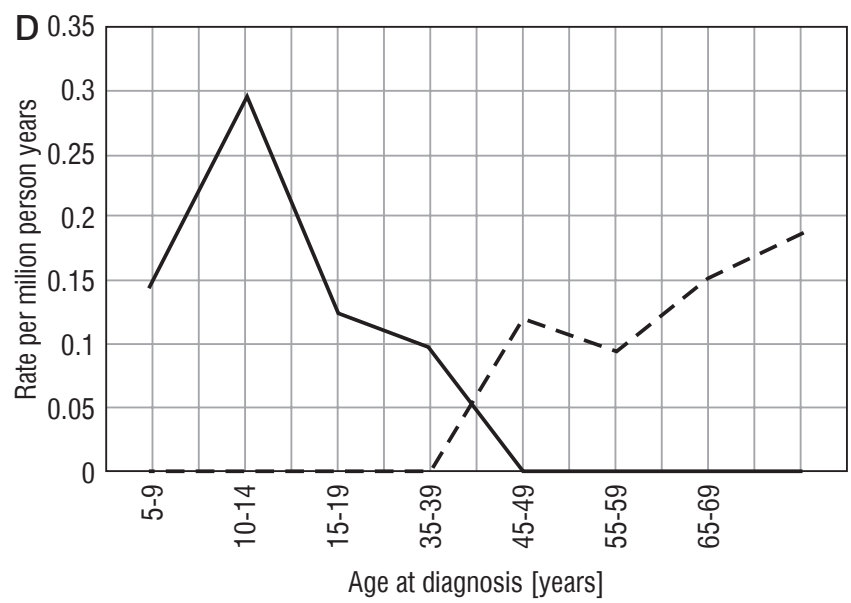

- - Women — Men

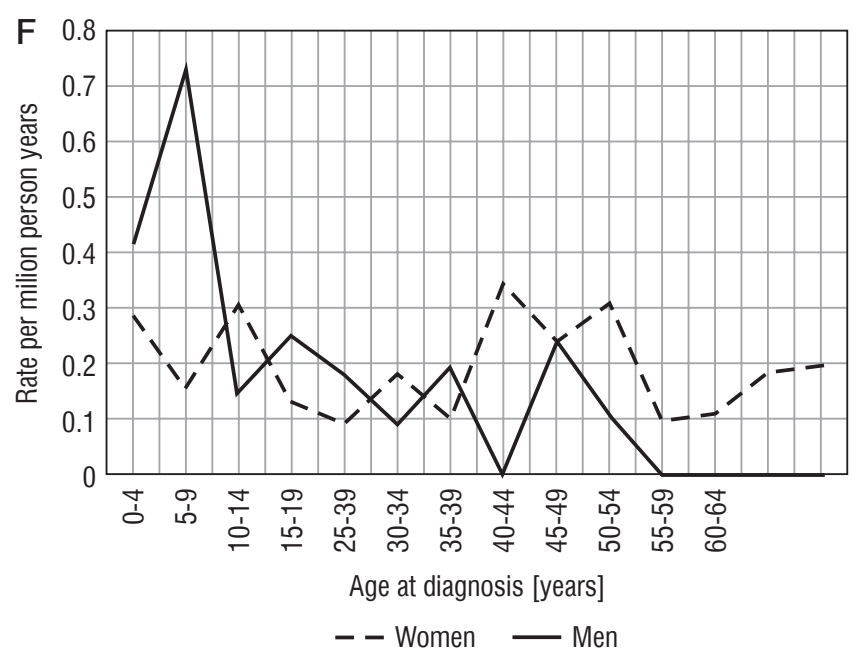

Figure 1. Age-specific incidence rate (per million person-years) of hospitalized patients with lysosomal storage diseases by subtypes, 2009-2015: A) E75.0 GM2 gangliosidosis; B) E75.1 Other gangliosidosis; C) E75.2 Other sphingolipidosis; D) E75.3 Sphingolipidosis, unspecified; E) E75.4 Neuronal ceroid lipofuscinosis; F) E75.5 Other lipid storage disorders; 


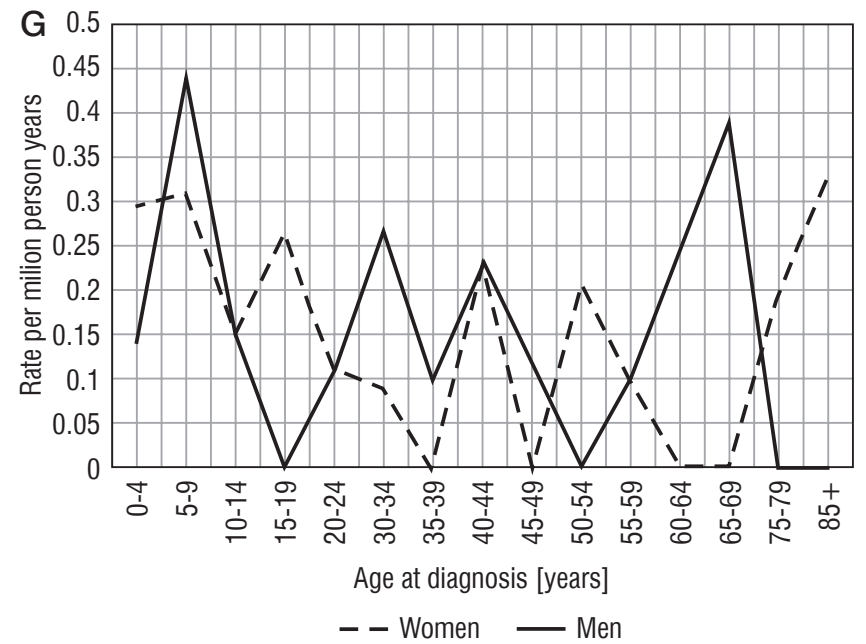

Figure 1 cont. Age-specific incidence rate (per million person-years) of hospitalized patients with lysosomal storage diseases by subtypes, 2009-2015: G) E75.6 Lipid storage disorder, unspecified

Table III. Regional differences in the incidence of lysosomal storage diseases

\begin{tabular}{|c|c|c|c|c|c|c|c|c|c|c|c|c|c|}
\hline \multirow[t]{2}{*}{ ICD10 } & \multirow{2}{*}{$\begin{array}{l}\text { Region of } \\
\text { residence }\end{array}$} & \multicolumn{4}{|c|}{ Men } & \multicolumn{4}{|c|}{ Women } & \multicolumn{4}{|l|}{ All } \\
\hline & & $\mathrm{N}$ & IR & $95 \% \mathrm{Cl}$ & & $\mathrm{N}$ & IR & $95 \% \mathrm{Cl}$ & & $\mathrm{N}$ & IR & $95 \% \mathrm{C}$ & \\
\hline \multirow[t]{6}{*}{ E75.0 } & Mazovia & 4 & 0.523 & 0.01 & 1.03 & & & & & 4 & 0.25 & 0 & 0.494986 \\
\hline & South-east & 2 & 0.149 & -0.06 & 0.35 & 2 & 0.1396 & -0.05 & 0.33 & 4 & 0.144 & 0 & 0.285024 \\
\hline & South-west & & & & & 1 & 0.1308 & -0.13 & 0.39 & 1 & 0.068 & -0.06 & 0.200219 \\
\hline & North-east & 4 & 0.572 & 0.01 & 1.13 & 1 & 0.1358 & -0.13 & 0.4 & 5 & 0.348 & 0.04 & 0.653853 \\
\hline & North-west & 4 & 0.286 & 0.01 & 0.57 & 2 & 0.1355 & -0.05 & 0.32 & 6 & 0.209 & 0.04 & 0.375895 \\
\hline & Silesia & 2 & 0.301 & -0.12 & 0.72 & 2 & 0.2809 & -0.11 & 0.67 & 4 & 0.291 & 0.01 & 0.57574 \\
\hline \multirow[t]{5}{*}{ E75.1 } & Mazovia & & & & & 1 & 0.1198 & -0.12 & 0.35 & 1 & 0.062 & -0.06 & 0.184995 \\
\hline & South-west & 1 & 0.14 & -0.13 & 0.41 & & & & & 1 & 0.068 & -0.06 & 0.200219 \\
\hline & North-east & 2 & 0.286 & -0.11 & 0.68 & & & & & 2 & 0.139 & -0.05 & 0.332537 \\
\hline & North-west & 1 & 0.072 & -0.07 & 0.21 & 2 & 0.1355 & -0.05 & 0.32 & 3 & 0.104 & -0.01 & 0.222552 \\
\hline & Silesia & 1 & 0.151 & -0.14 & 0.45 & 2 & 0.2809 & -0.11 & 0.67 & 3 & 0.218 & -0.03 & 0.464867 \\
\hline \multirow[t]{6}{*}{ E75.2 } & Mazovia & 10 & 1.306 & 0.5 & 2.12 & 8 & 0.9586 & 0.294 & 1.62 & 18 & 1.125 & 0.61 & 1.644676 \\
\hline & South-east & 23 & 1.709 & 1.01 & 2.41 & 14 & 0.9769 & 0.465 & 1.49 & 37 & 1.332 & 0.9 & 1.760609 \\
\hline & South-west & 9 & 1.261 & 0.44 & 2.09 & 5 & 0.6538 & 0.081 & 1.23 & 14 & 0.947 & 0.45 & 1.443042 \\
\hline & North-east & 5 & 0.716 & 0.09 & 1.34 & 10 & 1.3582 & 0.516 & 2.2 & 15 & 1.045 & 0.52 & 1.574304 \\
\hline & North-west & 5 & 0.358 & 0.04 & 0.67 & 8 & 0.542 & 0.166 & 0.92 & 13 & 0.452 & 0.21 & 0.698366 \\
\hline & Silesia & 13 & 1.959 & 0.89 & 3.02 & 7 & 0.9833 & 0.255 & 1.71 & 20 & 1.454 & 0.82 & 2.091082 \\
\hline
\end{tabular}


Table III cont. Regional differences in the incidence of lysosomal storage diseases

\begin{tabular}{|c|c|c|c|c|c|c|c|c|c|c|c|c|c|}
\hline \multirow{3}{*}{$\begin{array}{l}\text { ICD10 } \\
\text { E75.3 }\end{array}$} & \multirow{3}{*}{$\begin{array}{l}\text { Region of } \\
\text { residence }\end{array}$} & \multicolumn{4}{|c|}{ Men } & \multicolumn{4}{|c|}{ Women } & \multicolumn{4}{|c|}{ All } \\
\hline & & \multirow{2}{*}{$\begin{array}{l}\mathrm{N} \\
1\end{array}$} & \multirow{2}{*}{$\begin{array}{l}\text { IR } \\
0.131\end{array}$} & \multicolumn{2}{|l|}{$95 \% \mathrm{Cl}$} & \multirow[t]{2}{*}{$N$} & \multirow[t]{2}{*}{ IR } & \multicolumn{2}{|l|}{$95 \% \mathrm{Cl}$} & \multirow{2}{*}{$\begin{array}{l}N \\
1\end{array}$} & \multirow{2}{*}{$\begin{array}{l}\text { IR } \\
0.062\end{array}$} & \multicolumn{2}{|c|}{$95 \% \mathrm{Cl}$} \\
\hline & & & & -0.13 & 0.39 & & & & & & & -0.06 & 0.184995 \\
\hline & South-west & 1 & 0.072 & -0.07 & 0.21 & & & & & 1 & 0.035 & -0.03 & 0.103014 \\
\hline & Silesia & 1 & 0.151 & -0.14 & 0.45 & & & & & 1 & 0.073 & -0.07 & 0.215175 \\
\hline \multirow[t]{5}{*}{ E75.4 } & Mazovia & 1 & 0.131 & -0.13 & 0.39 & 3 & 0.3595 & -0.05 & 0.77 & 4 & 0.25 & 0 & 0.494986 \\
\hline & South-east & & & & & 4 & 0.2791 & 0.006 & 0.55 & 4 & 0.144 & 0 & 0.285024 \\
\hline & North-east & 1 & 0.143 & -0.14 & 0.42 & 1 & 0.1358 & -0.13 & 0.4 & 2 & 0.139 & -0.05 & 0.332537 \\
\hline & North-west & 1 & 0.072 & -0.07 & 0.21 & 1 & 0.0678 & -0.07 & 0.2 & 2 & 0.07 & -0.03 & 0.16607 \\
\hline & Silesia & 1 & 0.151 & -0.14 & 0.45 & 1 & 0.1405 & -0.13 & 0.42 & 2 & 0.145 & -0.06 & 0.346887 \\
\hline \multirow[t]{6}{*}{ E75.5 } & Mazovia & & & & & 1 & 0.1198 & -0.12 & 0.35 & 1 & 0.062 & -0.06 & 0.184995 \\
\hline & South-east & 2 & 0.149 & -0.06 & 0.35 & 2 & 0.1396 & -0.05 & 0.33 & 4 & 0.144 & 0 & 0.285024 \\
\hline & South-west & & & & & 1 & 0.1308 & -0.13 & 0.39 & 1 & 0.068 & -0.06 & 0.200219 \\
\hline & North-east & 1 & 0.143 & -0.14 & 0.42 & 2 & 0.2716 & -0.1 & 0.65 & 3 & 0.209 & -0.03 & 0.445636 \\
\hline & North-west & & & & & 1 & 0.0678 & -0.07 & 0.2 & 1 & 0.035 & -0.03 & 0.103014 \\
\hline & Silesia & 1 & 0.151 & -0.14 & 0.45 & 1 & 0.1405 & -0.13 & 0.42 & 2 & 0.145 & -0.06 & 0.346887 \\
\hline \multirow[t]{5}{*}{ E75.6 } & Mazovia & 1 & 0.131 & -0.13 & 0.39 & & & & & 1 & 0.062 & -0.06 & 0.184995 \\
\hline & South-east & 3 & 0.223 & -0.03 & 0.48 & 1 & 0.0698 & -0.07 & 0.21 & 4 & 0.144 & 0 & 0.285024 \\
\hline & South-west & 1 & 0.14 & -0.13 & 0.41 & & & & & 1 & 0.068 & -0.06 & 0.200219 \\
\hline & North-east & 4 & 0.572 & 0.01 & 1.13 & 1 & 0.1358 & -0.13 & 0.4 & 5 & 0.348 & 0.04 & 0.653853 \\
\hline & North-west & 2 & 0.143 & -0.06 & 0.34 & 1 & 0.0678 & -0.07 & 0.2 & 3 & 0.104 & -0.01 & 0.222552 \\
\hline
\end{tabular}

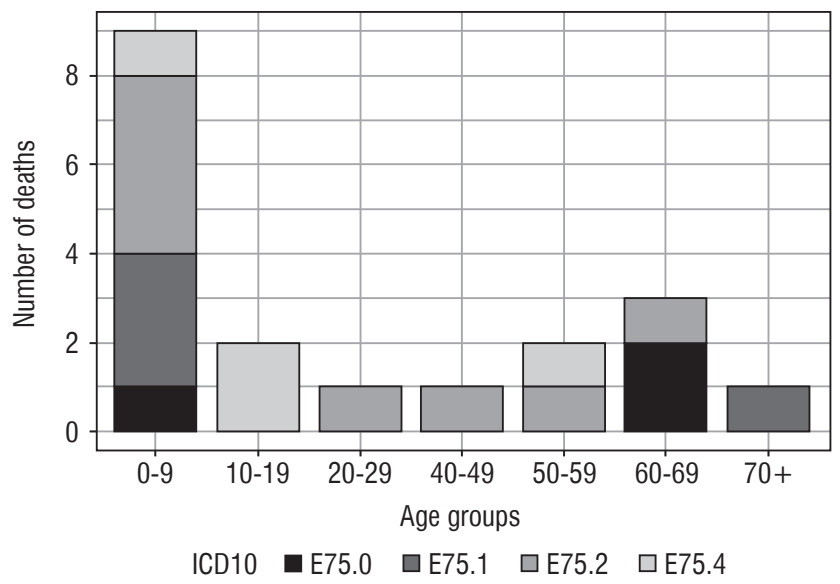

Figure 2. Number of deaths in patients with lysosomal storage diseases hospitalized between the years 2013 and 2015
Health Found is the payer for medical services received by all insured subjects.

Only scarce epidemiological data for lysosomal storage diseases were published in the past [2].

As indicated in our paper, the number of patients hospitalized in Poland in 2013-2015 due to lysosomal storage diseases was 212 (incidence rate 1.84 patients/million habitants * year). The most common reason for hospitalization due to the abovementioned conditions was so-called other sphingolipidosis (incidence rate 1.1 patients/million habitants * year). The next most common reason for the frequency of hospitalization due to lysosomal storage diseases were GM2 gangliosidosis sphingolipidosis (incidence rate 0.25 patients/million habitants * year) (Table I).

The number of data on the incidence of lysosomal storage diseases is very limited. In the work of Kingma et al. [2] the data from the literature on the above-mentioned topic are summarized. However, in the analysed studies, there was no necessity 
for hospitalization, but only birth prevalence of lysosomal storage diseases in Australia, the Netherlands, British Columbia, Portugal, the Czech Republic, and the United Arab Emirates [6-8, 10, 15]. This disease ranged from 7.5/100,000 births in British Columbia to 23.5/100,000 births in the United Arab Emirates $[10,15]$. These data are difficult to compare with the data obtained by us. As can be seen from the above that the risk of birth prevalences of lysosomal storage diseases in the abovementioned countries was significantly higher than in Polish conditions. However, it should be admitted that the cited studies considered the birth prevalence of lysosomal storage diseases, whereas in our work we examined only the patients hospitalized due to lysosomal storage diseases. This could be one of the main reasons for the differences in the obtained test results. We believe, however, that this does not explain the fully proven differences. We are of the opinion that the differences could also result from the fact that Poland is a country in which only people of Polish origin live in the vast majority, and hence the frequency of mutations in the genes responsible for the occurrence of lysosomal storage diseases can be relatively small, whereas in people of other origin (unlike other analysed countries) [7, 8, $10,15]$ this frequency is significantly higher. The reason for the differences may also be an imperfect system of recognizing these diseases in our country. Screening programs for lysosomal storage diseases may prevent irreversible organ damage. Poland lacks this program. However, interestingly, as in our observation, the most common lysosomal storage diseases were sphingolipidosis, followed by gangliosidosis (Table I) [2].

The incidence of hospitalization due to lysosomal storage diseases was significantly higher in men (IR 2.15, 95\% Cl: $1.76-$ 2.53) than in women (IR = 1.84, 95\% Cl: 1.59-2.0) (Table II). In the available literature, we were unable to find work on differences in morbidity due to lysosomal storage diseases between women and men (Table II). Therefore, no justification for these differences was found. Perhaps some of these conditions also depend on changes in the $\mathbf{X}$ chromosome. $\mathbf{X}$-linked recessive with incomplete penetrance in heterozygous females. The condition affects hemizygous males (i.e. all males), as well as homozygous, and in many cases heterozygous females. While males typically experience severe symptoms, women can range from being asymptomatic to having severe symptoms. New research suggests that many women suffer from hypertrophic left ventricular heart problems and kidney failure. These $X$-inactivation patterns during embryonic development of the female chromosome $X$ occur only 1 time in men. In this situation, it is more likely to reveal recessive changes characteristic, for example, for Fabry's disease.

Hospitalizations due to lysosomal storage diseases were most common in young people (up to 24 years of age) with the exception of hospitalization caused by lipid storage diseaseunspecified (Fig. 1). Lysosomal storage diseases occur at a young age; hence, the fact that the necessity of hospitalization takes place at a young age is beyond doubt. Due to poor prognosis in patients with lysosomal storage diseases, the inci- dence of hospitalization at a later age is less frequent (Fig. 1) This is consistent with the data presented in Figure 2. In turn, the highest mortality rate (as expected) was demonstrated in people aged 0-9 years (Table II).

The study also analysed the frequency of hospitalization due to lysosomal storage diseases in various regions of our country (Table III). Because the number of hospitalizations, in general, was small due to the rarity of these diseases, there were no significant differences between individual regions of Poland (Table III). The number of patients hospitalized in Poland due to lysosomal storage diseases in the years 2013-2015 was relatively small. After dividing into individual regions, we had to deal only with individual cases in individual parts of the country. For this reason, the analysis did not bring new cognitive elements.

\section{Study limitations}

Certain errors may be suspected in our analysis.

First, it is not absolutely certain that all the cases of lysosomal storage diseases belonged to that group of patients. A more precise diagnostic analysis would have qualified the cases to another group.

Second, we may suspect that some cases of lysosomal storage diseases, especially in patients of health centres in smaller towns or in rural environments, were not properly diagnosed. This is perhaps the reason for the significantly lower incidence of lysosomal storage diseases in the general Polish population, when compared to other populations.

Nonetheless, we present, for the first time, complete and reliable data on the incidence rate of lysosomal storage diseases in Poland. This may help better understand this issue, providing improved diagnostics of this specific condition and, consequently, ensuring more targeted treatment.

\section{Conclusions}

The incidence rate of lysosomal storage diseases in Poland is about 1.84 per million person-years. Other sphingolipidosis (E75.2) was the largest disease category, with 127 patients (incidence 1.1 patients/milion habitants), followed by GM2 gangliosidosis (E75.0), with 29 patients (incidence 0.25 patients/ million habitants). The hospitalization rate of lysosomal storage diseases was higher in mar than women. No statistically significant differences were observed among the recorded incidence rates obtained at the analysed Polish regions.

\section{Acknowledgements}

This reported study was carried out as a part of the project "Maps of Health Needs - Database of Systemic and Implementation Analyses". The project is co-financed by the European Union from the European Social Fund and is being carried out by the Analyses and Strategies Department of the Polish Ministry of Health. 


\section{References}

1. Folicamoi M, Morrone A. Lysosomal storage disorders: basis and laboratory testing. Hum Genomics 2011; 5: 156-169.

2. Kingma SDK, Bodamer OA, Wijburg FA. Epidemiology and diagnosis of lysosomal storage disorders: challenges of screening. Best Pract and Clin Endocrinol and Metab 2015; 290: 145-157. doi: 10.1016/j.beem.2014.08.004.

3. Kishnani PS, Amartino HM, Lidberg C, et al. Timing of diagnosis of patients with Pompe disease: data from Pompe registry. Am J Hum Genet 2013; 161: 2431-2443. doi: 10.1002/ajmg.a.36110.

4. Smith NJ, Winstone AM, Stellitano L, et al. GM2 gangliosidosis in a UK study of children with progressive neurodegeneration: 73 cases reviewed. Dev Med Child Neurol 2012; 54: 176-182. doi: 10.1111/j.1469-8749.2011.04160.x.

5. Wilcox WR. Lysosomal storage disorders: the need for better pediatric recognition and comprehensive vare. J Pediatr 2004; 144: S3S14. doi: 10.1016/j.jpeds.2004.01.049.

6. Meikle PJ, Hopwood JJ, Clague AE, et al. Prevalence of lysosomal storage disorders. J Am Med Assoc 1999; 281: 249-254. doi: 10.1001/jama.281.3.249.

7. Poorthuis BJ, Wevers RA, Kleijer WJ, et al. The frequency of lysosomal storage diseeases in The Netherlands. Hum Genet 1999; 105: 151-156. doi: 10.1007/s004399900075.

8. Pinto R, Caseiro C, Lemos M, et al. Prevalence of lysosomal storage diseases in Portugal. Eur J Hum Genet 2004; 12: 87-92. doi: 10.1038/sj.ejhg.5201044.
9. Poupetova H, Ledvinova J, Berna L, et al. The birth prevalence of Iysosomal storage disorders in the Czech Republic, comparison with data in different populations. J Inherit Metab Disord 2010; 33: 387-396. doi: 10.1007/s10545-010-9093-7.

10. Al-Jasmi FA, Tawfig N, Berniah A, et al. Prevalence and novel mutations of lysosomal storage disorders in United Arab Emirates: LSD in UAE. J Inherit Metab Disord Rep 2013; 10: 1-9. doi: 10.1007/8904_2012 182.

11. Chaing SC, Hwu WL, Lee NC, et al. Algorithm for Pompe disease newborn screening: results from the Taiwan screening program. Mol Genet Metab 2012; 106: 281-286. doi: 10.1016/j. ymgme.2012.04.013.

12. Liao HC, Chaing CC, Niu DM, et al. Detecting multiple lysosomal storage diseases by tandem mass spectometry - a national newborn screening program in Taiwan. Clin Chim Acta 2014; 431: C8086. doi: 10.1016/j.cca.2014.01.030.

13. Inoue $T$, Hattori $K$, Ihara $K$, et al. Newborn creening for Fabry disease in Japan: prevalence and genotypes of Fabry disease in a pilot study. J Hum Genet 2013; 58: 548-552. doi: 10.1038/ jhg.2013.48.

14. Spada M, Pagliardini S, Yasuda M, et al. High incidence of lateronset Fabry disease revealed by newborn screening. Am J Humen Genet 2006; 79: 31-40. doi: 10.1086/504601.

15. Applegarth DA, Toone JR, Lowry RB. Incidence of inborn errors of metabolism in British Coulumbia, 1969-1996. Pediatrics 2000; 105: e10. doi: 10.1542/peds.105.1.e10. 